\title{
Estimation of Genetic Parameters of Cayenne Peppers (Capsicum Annuum L.) from IPB University for Its Resistance Against Begomoviruses in Aceh
}

\author{
Siti Hafsah ${ }^{* 1}$, Aiyu Ardika1, Erita Hayati1, Firdaus Firdaus ${ }^{2}$ \\ ${ }^{1}$ Department of Agrotechnology, Faculty of Agriculture, Universitas Syiah Kuala \\ Jl. Hasan Krueng Kalee, No 3, Kopelma Darussalam, 23111, Banda Aceh, Indonesia \\ ${ }^{2}$ Assessment Institute of Agricultural Technology of Aceh \\ Jl. Panglima Nyak Makam, Lampineung 23125, Banda Aceh, Indonesia \\ *Corresponding author: sitihafsah@unsyiah.ac.id
}

\section{ARTICLE HISTORY}

\section{Received : 25 July 2020 \\ Revised : :17 August 2020 \\ Accepted : 11 September 2020}

\section{KEYWORDS}

Resistance;

Genotype;

Disease Intensity;

Heritability;

Selection;

\begin{abstract}
The productivity of pepper plants is strongly influenced by climatic and weather conditions as well as pests and diseases. One of the major losses in chili farming is the pest attack, such as whiteflies (Bemisia tabaci Genn.), a virus vector. Evaluation of the resistance of pepper plant germplasm against Begomovirus infection needs to be carried out, evaluate genetic diversity, estimate heritability values, and obtain a selection character for the resistance of chili plants Begomovirus. This research was conducted at Experimental Garden, Faculty of Agriculture, Universitas Syiah Kuala, and the Laboratory of Genetics and Plant Breeding, Faculty of Agriculture, Universitas Syiah Kuala from January to May 2020. Three varieties Gada, Anies and Selekta with seven test genotypes i.e F6 Gada, Seloka 4-10-2-2, F5136074-1-4-3, F5074136-2-3-2, F5074035-2-1-2, F5074035-2-4-2, F5074077-1-1-3 were screened for their resistance against Begomovirus. This study was designed using a non-factorial Randomized Block Design (RBD) and scoring parameter Begomovirus symptom. Tukey's HSD, the standard deviation of genetic variance, heritability, and correlation were performed to analyze the data. The lowest disease intensity occurred in genotype F6 Gada with a percentage of $12.08 \%$ disease intensity (slightly resistant), and the highest level of disease intensity occurred in F5074035-2-4-2 with a percentage of 30.94\% (susceptible). Variables symptom scoring, disease intensity, and incubation period were the most effective variables for selecting pepper resistance against Begomovirus

infection based on broad-sense heritability values.
\end{abstract}

This is an open access article under the CC-BY-SA license.

\section{INTRODUCTION}

Pest attack is one of the important causes of a significant loss in pepper crop. Insect Silverleaf whitefly is a virus vector for Begomovirus, a virus causing chilli leaf curl disease (Parining \& Dewi, 2018; Yadav, et al., 2020). Yellow leaf curl disease has attacked pepper plants in Indonesia reached up to 4537.8 ha in 2016 and has increased to 4591.9 ha in 2017 and 4986.4 ha in 2018 (Kementerian Pertanian, 2019). The research of Koeda, et. al. (2016) found that 500-3000 pepper plants planted by farmers, 4 out of 5 plantations have been attacked by this virus $100 \%$.

The application of resistant varieties is still the most effective way to reduce plant diseases caused by Begomovirus. Varieties Anies and Seloka are some resistant varieties produced from hybridization between IPB C120 x IPB C5 and IPB C2 x IPB C5. Ganefianti (2010) has assessed several pepper genotypes against Begomovirus. Variety IPB C5 was one of them. This variety was tested and was very susceptible to Begomovirus attack with a disease intensity $40 \%$.
Variety IPB C12 was found to be resistant against Begomovirus. This potential genotype can be used as resistant varieties assembly.

Resistant varieties were obtained through plant breeding techniques. The study of cayenne pepper resistance against Begomovirus should include the assays of its genetic diversity, determination of heritability value and evaluation of its resistance to Begomovirus. The objective of this research was to determine cayenne pepper genotypes and varieties which resistant to Begomovirus attack.

\section{MATERIALS AND METHODS}

\subsection{Place and Duration}

This research was conducted in Experimental Garden, , Faculty of Agriculture, Universitas Syiah Kuala from January - May 2020. The observation for cayenne pepper production was conducted in Genetics and Plant Breeding Laboratory and also Horticulture Laboratory. The materials used in this research were cavenne pepper from 
IPB University, seven genotypes tested with three other varieties as a comparison. Those seven genotypes tested were F6 Gada, Seloka 4-10-2-2, F5 136074-1-4-3, F5 074136-2-3-2, F5 074035-2-1-2, F5 074035-2-4-2, F5 074077-1-1-3, with 3 varieties as a comparison such as F1 Gada, Anies and Selekta, planting media provided with compost and husk charcoal (ratio 1:1), black and silver plastic mulch film, metal wires used to tighten the plastic mulch film in covering the beds, manure, fertilizer AB mix, and insecticide Agrimec (Abamectin $8 \mathrm{~g} \mathrm{~L}-1$ ) to control thrips pest. The tools used in this research were hoes, bamboo stakes, water source, raffia rope, transparent plastics, measuring tape, analytical balance, hand sprayer, trays, scissors, pinset, ruler, and stationery.

\subsection{Research Methods}

This research employed Randomized Block Design (RBD) Non-Factorial with three replications, where each replication was consist of seven genotypes assessed and three comparing varieties. There were 30 experimental units with 20 plants for each experiment resulted in 600 experimental plants in total. The sampled plants are also used for disease attack observation.

\subsubsection{Seed Sowing}

The pepper seeds were sowed in a 50-hole-tray. The media (compost+husk charcoal) were placed evenly. Insecticide Agrimec was used to control pest and disease attack, applied with a concentration of $0.5 \mathrm{ml} / \mathrm{L}$. AB mix was applied to fertilize the plants with a concentration 5 $\mathrm{ml} / \mathrm{L}$.

One month before planting, the field needed to be tilled through plowing to loose the soil. The beds were made in size $5 \mathrm{~m} \times 1 \mathrm{~m}$. The manure, $10 \mathrm{~kg}$ per bed, was applied two weeks before replanting. The distance between the experimental plots was $0.5 \mathrm{~m}$, and the spacing was $50 \mathrm{~cm} \times 50 \mathrm{~cm}$. The beds then were covered with black and silver mulch plastic films that were applied in the afternoon to be stretched (Wijayanto, 2018). The mulch films should be stretched and tighten, and bamboo stakes were applied at each end of the beds, and each end of mulch was inserted into the stakes to keep the mulch films tightened.

\subsubsection{Seed Replanting}

Seed replanting was done five weeks after sowing, where these seeds reached $\pm 10 \mathrm{~cm}$ in height and already have 5-7 leaves. The replanting activity was done in the evening (5-6 pm) to avoid sunlight exposure. One seed for one hole, each plot was planted with 20 plants. The stakes and raffia were installed three days after planting. The installation of stakes (1.5 $\mathrm{m}$ at each hole) was important to avoid this replanting cayenne from being struck with the mulch films due to the gust of wind.

Fruit harvesting was done by picking the fruits and its stalks when it was $75 \%$ - $100 \%$ ripe. This harvesting activity is done once a week for four weeks.

\subsection{Variables Observed \\ 2.3.1. Incubation Period}

Begomovirus incubation period in sampled plants was observed daily after the plants were infected, manifested by thickening of midrib and yellowing of leaf lamina.

\subsubsection{Scoring/Symptom Type}

This variable was observed using the leaf symptom score explained by Ganefianti (2008) in the table below

Table 1. Leaf Symptom Score

\begin{tabular}{ll}
\hline $\begin{array}{c}\text { Severity } \\
\text { score }\end{array}$ & \multicolumn{1}{c}{ Symptom } \\
\hline 0 & Healthy, no lesions \\
1 & Yellowing lamina, mosaic on leaves \\
2 & Curl and yellow leaves \\
3 & Yellowing, upward and downward leaf curling \\
4 & Yellowing, upward and downward leaf curling \\
5 & Yellowing, upward and downward leaf curling and \\
& dwarf \\
\hline
\end{tabular}

\subsubsection{Disease Intensity}

The disease intensity was calculated in the interval 15 days based on the symptoms described in Table 1 . Plant resistance was categorized by Ganefianti (2010) in Table 2. The disease Intensity was recorded. This variable was recorded using the formula:

$$
\text { Disease Intensity (\%) }=\frac{\sum_{0}^{i=5}(n i x z i)}{N \times Z} \times 100 \%
$$

Where:

$\mathrm{ni}=$ number of diseased plants on the $i$ th grade

$\mathrm{zi}=$ numerical value of $i$ ts category

$\mathrm{N}=$ total number of plants evaluated

$\mathrm{Z}=$ the highest numerical value

Table 2. Resistance categories of plants against Begomovirus

\begin{tabular}{lll}
\hline Category & Symptoms & Disease intensity \\
\hline Resistant & Mild & $1 \%<\mathrm{IP} \leq 10 \%$ \\
Moderate & Moderate & $10 \%<\mathrm{IP} \leq 20 \%$ \\
Susceptible & Severe & $20 \%<\mathrm{IP} \leq 40 \%$ \\
Highly susceptible & Severe & $\mathrm{IP}>40 \%$ \\
\hline
\end{tabular}

\subsection{Data Analysis}

1. Genotypic variance $\left(\sigma^{2} \boldsymbol{g}\right)$ was calculated using the formula of Singh \& Chaudary (1979):

$$
\sigma^{2} \mathbf{g}=(\text { MSG-MSe }) / \mathbf{r}
$$

Where:

$\begin{array}{ll}\text { MSG } & =\text { mean square of genotype } \\ \text { MSe } & =\text { mean square of error } \\ r & =\text { replication }\end{array}$

2. Genotypic coefficient of variability (GCV) was measured using the formula: 


$$
\left.\mathrm{GCV}=\left(\begin{array}{ll}
\sqrt{x} & \sigma^{2} \mathrm{~g}
\end{array}\right) / \mathrm{x}\right) \times 100 \%
$$

Where:

$x=$ grand mean

$\sigma^{2} \mathrm{~g}=$ genetic variance

The categorization of GCV by Qosim, at al. (2020) as explained below:

Table 3. Categorization of GCV

\begin{tabular}{ll}
\hline \multicolumn{1}{c}{ GCV } & \multicolumn{1}{c}{ Category } \\
\hline $0<\mathrm{X} \leq 10.94$ & Narrow \\
$10.94<\mathrm{X} \leq 21.88$ & slightly narrow \\
$21.88<\mathrm{X} \leq 32.83$ & slightly broad \\
$32.83<\mathrm{X} \leq 43.77$ & Broad \\
$43.77<\mathrm{X}$ & Highly broad \\
\hline
\end{tabular}

\section{Phenotypic coefficient of variability (PCV)}

was Measured using the formula:

$$
\begin{gathered}
\left.\mathrm{PCV}=\left(\sqrt{x} \sigma^{2} \mathrm{f}\right) / \mathrm{x}\right) \times 100 \% \\
\text { Where: }
\end{gathered}
$$

$x \quad=$ grand mean

$\sigma^{2} \mathrm{f} \quad=$ fenotypic variance $=\left(\sigma^{2} \mathrm{~g}+\sigma^{2} \mathrm{e} / \mathrm{n}\right)$

$\sigma^{2} \mathrm{~g} \quad=$ genotypic variance

$\sigma^{2} \mathrm{e}=$ MSe $=$ mean square of error, determined by the environment in the location

The categorization of PCV by Qosim, at al. (2020) as explained below:

Table 4. Categorization of GCV

\begin{tabular}{ll}
\hline GCV & Category \\
\hline $0<\mathrm{X} \leq 24.94$ & Narrow \\
$24.94<\mathrm{X} \leq 49.71$ & slightly narrow \\
\hline
\end{tabular}

$\begin{array}{ll}49.71<\mathrm{X} \leq 74.71 & \text { slightly broad } \\ 74.71<\mathrm{X} \leq 99.65 & \text { Broad } \\ 99.65<\mathrm{X} & \text { Highly broad }\end{array}$

4. Heritability in a broad sense $\left(\mathbf{H}^{2} \mathbf{B}\right)$. This variable was recorded using the formula:

Where:

$$
\mathrm{H}^{2} \mathrm{~B}=\left(\sigma^{2} \mathrm{~g} / \sigma^{2} \mathrm{f}\right) \times 100 \%
$$

$\sigma^{2} \mathrm{~g} \quad=$ genotypic variance

$\sigma^{2} \mathrm{f} \quad=$ fenotypic variance

Category of Heritability by Zen \& Bahar (1996):

Table 5. Categorization of Heritability

\begin{tabular}{ll}
\hline \multicolumn{1}{c}{ Heritability } & \multicolumn{1}{c}{ Category } \\
\hline $0<\mathrm{X}<20$ & Low \\
$20 \leq \mathrm{X}<50$ & Moderate \\
$50 \leq \mathrm{X}$ & High \\
\hline
\end{tabular}

\section{RESULTS AND DISCUSSIONS}

\subsection{Plant Resistance Against Begomovirus}

Several symptoms were shown by plants infected by Begomovirus, such as midrib thickening and midrib thickening. The midrib was a yellow mosaic on leaves, yellowing on some parts of leaf lamina, yellowing followed by downward leaf curling, smaller leaves and yellowing followed by upward and downward leaf curling dwarf. Also, there was a symptom where the leaves were smaller, yellowing, and upward leaf curling, as described in Figure 1.
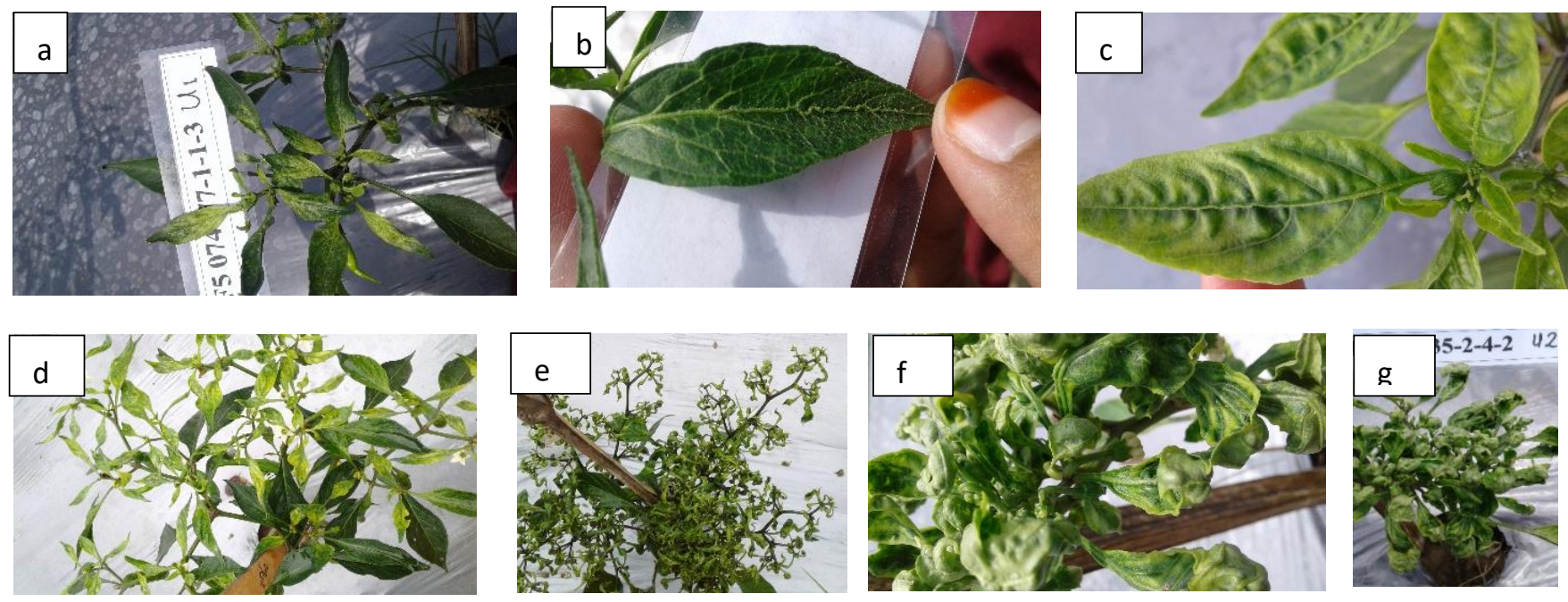

Figure 1. Several Symptoms are shown by plants infected with Begomovirus. a) yellowing of lamina leaf. b) Thickening and irregular shape of the midrib, c) midrib thickening followed by yellow mosaic on leaves, d) yellowing leaves, e) the leaves were smaller in size and experienced upward and downward leaf curling, f) upward and downward leaf curling, and g) leaf yellowing, upward and downward leaf curling and dwarf. 
The increase of viral infection was linear with the increase of plant age and vector population. The increase of the whitefly population has escalated the chance of infection by the virus. Different virus species attributed the difference of symptom shown by the infected plants. Upward leaf curling and mosaic are found in pepper plants and found in other plants such as tomato, which is infected by TYLCV (Tomato Yellow Leaf Curl Virus), and bean, which is infected by BCMV (Bean Common Mosaic Virus). Different soil fertility levels, climate, plant age, and plant genotype have also contributed to these different symptoms (Hannum, et al., 2019).

Table 6. The incubation period, disease intensity, and resistance category of plants infected by Begomovirus

\begin{tabular}{lccc}
\hline \multicolumn{1}{c}{ Sampled plants } & The incubation period (DAP) & Disease intensity (\%) & Resistance Category \\
\hline F6 Gada & $48.51 \mathrm{~d}$ & $12.08 \mathrm{a}$ & Intermediate-resistant \\
Seloka 4-10-2-2 & $38.35 \mathrm{c}$ & $17.85 \mathrm{abc}$ & Intermediate-resistant \\
F5136074-1-4-3 & $39.73 \mathrm{c}$ & $16.53 \mathrm{ab}$ & Intermediate-resistant \\
F5074136-2-3-2 & $34.48 \mathrm{abc}$ & $26.53 \mathrm{~cd}$ & Susceptible \\
F5074035-2-1-2 & $30.73 \mathrm{ab}$ & $18.96 \mathrm{abc}$ & Intermediate-resistant \\
F5074035-2-4-2 & $28.88 \mathrm{a}$ & $30.94 \mathrm{~d}$ & Susceptible \\
F5074077-1-1-3 & $38.78 \mathrm{c}$ & $20.76 \mathrm{abc}$ & Susceptible \\
F1 Gada & $40.22 \mathrm{c}$ & $18.40 \mathrm{abc}$ & Intermediate-resistant \\
Anies & $37.28 \mathrm{bc}$ & $15.90 \mathrm{ab}$ & Intermediate-resistant \\
Selekta & $38.51 \mathrm{c}$ & $23.82 \mathrm{bcd}$ & Susceptible \\
\hline \multicolumn{1}{c}{ Tukey's HSD } & 9.36 &
\end{tabular}

Figures followed by the same letters in the same column do not differ significantly as determined by Tukey's Honest Significant Difference Test at $5 \%$ probability level

Table 6 described that the incubation period and disease intensity varied. The longest incubation period by Begomovirus was found in genotype F6 Gada (48.51 DAP), and this was significantly different compared to other genotypes and varieties. Genotype F5074035-2-4-2 has experienced the highest disease intensity (30.94\%). This result was insignificant compared to genotype F5074136-2-3-2 and variety Selekta, but it was significantly different compared to genotypes F6 Gada, Seloka 4-10-2-2, F5136074-1-4-3, F5074035-2-1-2, F5074077-1-1-3, and varieties F1 Gada and Anies. The lowest disease intensity was possessed by genotype $\mathrm{F} 6$ Gada (12.08\%).

A plant from genotype F5074035-2-4-2 demonstrated the shortest period of incubation (15 DAP) with symptoms of curling and yellowing leaves and dwarfism. This dwarfism disabled plants from producing flowers resulted in the inability to produce fruits. When Begomovirus attacks susceptible plants in their early development, the plants will experience dwarfism. When this infection happens in later development, the infection will not have a significant effect to yield. However, the vegetative phase's attack will significantly decrease the yield (Ganefianti, et al., 2017).

The information about plant response towards the disease symptoms is not enough to evaluate plant resistance. Therefore, the observation and estimation of disease intensity caused by Begomovirus are essentially needed. Disease intensity is the percentage of infection, colonization, and tissue damage caused by pathogens. Rating scale or scoring was employed to determine the disease intensity. Regarding to its score, there were six tested plants which considered into intermediateresistant category i.e F6 Gada, Seloka 4-10-2-2, F5136074-1-4-3, F5074035-2-1-2, F1 Gada and Anies. The other 4 tested plants (F5074136-2-3-2, F5074035-2-4-2, F5074077-1-1-3 and Selekta) were considered susceptible to Begomovirus attack.

\subsection{Study of Resistance Genes}

The diversity observed in character influences by two factors, genetic and environment. If there is a high genetic variance with low fenotypic variance in a population, its filial will have similar characteristics genetically. This broad variance of genetics is substantial in the selection process, enables us to select the best genotype (Allard, 1960). The measurement of genotypic variance, phenotypic variance, error variance, genotypic coefficient of variability, phenotypic coefficient of variability and heritability from variables disease incidence, rating scale/scoring, disease intensity and incubation period were presented in Table 7. 


\begin{tabular}{|c|c|c|c|c|c|}
\hline Variables & Genotypic variance & Phenotypic variance & Error variance & Heritabillity (\%) & Category \\
\hline Rating scale/symptom & 0.14 & 0.15 & 0.03 & 92.96 & High \\
\hline Disease intensity & 27.37 & 30.78 & 10.22 & 88.93 & High \\
\hline Incubation period & 27.69 & 29.60 & 5.73 & 93.55 & High \\
\hline
\end{tabular}

Note: $0<\mathrm{h}^{2} \mathrm{bs}<20=$ Low heritability, $\quad 20 \leq \mathrm{h}^{2}{ }_{\mathrm{bs}}<50=$ moderate, $\quad \mathrm{h}^{2} \mathrm{bs} \geq 50=$ high (Zen \& Bahar, 1996).

Table 8. Estimation of genotypic and phenotypic variances

\begin{tabular}{lcccc}
\hline \multicolumn{1}{c}{ Variables } & $\begin{array}{c}\text { Genotypic coefficient of } \\
\text { variability (GCV)(\%) }\end{array}$ & Category & $\begin{array}{c}\text { Phenotypic coefficient of } \\
\text { variability (PCV) (\%) }\end{array}$ & Category \\
\hline Rating scale/symptom & 28.51 & Slightly broad & 29.57 & Slightly narrow \\
Disease intensity & 116.48 & Highly broad & 123.51 & Highly broad \\
Incubation period & 85.88 & Highly broad & 88.79 & Broad \\
\hline
\end{tabular}

Note: GCV: narrow $(0 \%<\mathrm{X} \leq 10.94 \%)$, slightly narrow $(10.94 \%<\mathrm{X} \leq 21.88 \%)$, slightly broad $(21.88 \%<\mathrm{X} \leq 32.83 \%)$, broad $(32.83 \%<\mathrm{X} 43.77 \%)$, highly broad $(X>43.77 \%)$. PCV: narrow $(0 \%<X \leq 24.94 \%)$, slightly narrow $(24.94 \%<X \leq 49.71 \%)$, slightly broad $(49.71 \%<X \leq 74.71 \%), \quad$ broad $(74.71 \%<X \leq 99.65 \%)$, highly broad $(X>99.65 \%)$ (Qosim et al., 2000).

Table 8 illustrated that the variables rating scale (scoring)/symptom, disease intensity and incubation period possessed broad genetic variance, where the value was two times higher than its standard deviation value. Tables 7 and 8 described that variable rating scale (scoring)/symptom demonstrated slightly broad of GCV (28.51\%) and slightly narrow PCV (29.57\%) and high heritability estimation (92.96). The variable disease intensity has confirmed its highly broad GCV (116.48\%), highly broad PCV (123.51), and high heritability estimation (88.93\%). Meanwhile, for the incubation period, this variable had highly broad of GCV $(85.88 \%)$, broad PCV (88.79), and high heritability estimation (93.55\%).

Heritability is an estimation of genetic variance towards phenotypic variance. If a plant possesses high heritability, its phenotypic character has been influenced mostly by genetic factors. Previous research conducted by Ganefianti, et al. (2015a) informed that variable scoring/ symptom had high broad-sense heritability. It is indicated that this variable has been controlled by the genetic factor, not an environmental factor.

In this study of pepper resistance against Begomovirus, we exploit the genotypes tested to have the lowest symptoms. Ganefianti (2015b) stated that variable scoring/symptom and disease intensity had been managed by three genetic components: additive, dominance, and gene interaction. Strong influence from dominance and gene interaction has enabled us to select resistant genotypes (to Begomovirus) by estimating disease intensity and symptom scoring system.

\section{CONCLUSIONS}

1. There were six genotypes/varieties have been tested to be resistant against Begomovirus: F6 Gada (12.08\%), Anies (15.90\%), F5136074-1-4-3 (16.53\%), Seloka 4-10-2-2 (17.85\%), F1 Gada (18.40\%) and F5074035-2-1-2 (18.96\%).

2. Variables symptom scoring, disease intensity, and incubation period demonstrated broad genetic variance, slightly broad to broad GCV, highly broad PCV for disease intensity, and broad PCV for the incubation period. These variables also exhibited high heritability estimation. With this high heritability, the selection was possible to be applied to the initial generation

3. Symptom scoring, disease intensity, and incubation period assays in pepper plants were effective to be considered as determination in selecting resistant pepper genotypes and varieties against Begomovirus.

\section{REFERENCES}

Allard, R. W. (1960). Principles of Plant Breeding, John Willey and Sons Inc. New York, 36.

Bahar, H., \& Zen, S. (1993). Parameter genetik pertumbuhan tanaman, hasil dan komponen hasil jagung. Zuriat, 4(1).

Ganefianti, D. W., Sujiprihati, S., Hidayat, S. H., \& Syukur, M. (2008). Metode penularan dan uji ketahanan genotipe cabai terhadap Begomovirus. Akta Agrosia, 11(2), 162-169.

Ganefianti, D. W. (2010). Genetik Ketahanan Cabai Terhadap Begomovirus Penyebab Daun Keriting Kuning dan Arah Pemuliaannya.

Ganefianti, D. W., Sri Hendrastuti, H., \& Muhamad, S. (2015a). Estimation of Genetic Parameters for Resistance to Begomovirus on Chilli Pepper Based on Joint Scaling Test ( Proceeding ISEPROLOCAL). International Seminar on Promoting Local Resources for Food and Health, 12-13 October, 2015, Bengkulu, Indonesia.

Ganefianti, D. W., Hidayat, S. H., \& Syukur, M. (2015b). Genetic Study of Resistance to Begomovirus on Chili Pepper by Hayman's Diallel Analysis. International Journal on Advanced Science, Engineering and Information Technology, 5(6), 426-432.

Ganefianti, D. W., Sri Hendrastuti, H., \& Muhamad, S. (2017). Susceptible Phase of Chili Pepper Due to Yellow Leaf Curl Begomovirus Infection.

Hannum, S., \& Aceh, R. M. (2019, July). Begomovirus Detection On Diseased Chili Plant (Capsicum annum L.) In Tanah Karo North Sumatera With PCR Techniques. In IOP Conference Series: Earth and Environmental Science (Vol. 305, No. 1, p. 012057). IOP Publishing.

Kementerian Pertanian. (2019). Statistik Iklim, Organisme Pengganggu Tanaman dan Dampak Perubahan Iklim. Pusat Data dan Sistem Informasi Pertanian. 76. Diakses dari: http://epublikasi.setjen.pertanian.go.id/arsip-buletin/157-iklim-op t-dan-dpi/654-buletin-data-iklim-opt-dan-dpi-triwulan-iv-2019.

Koeda, S., Kesumawati, E., Tanaka, Y., Hosokawa, M., Doi, M., \& Kitajima, A (2016). Mixed infection of begomoviruses on pepper plants at northern Sumatra, Indonesia. Tropical Agriculture and Development, 60(2), 59-64. 
Parining, I. N., \& Dewi, I. R. K. (2018). Analisis Risiko Pendapatan Cabai Merah Pada Lahan Sawah Dataran Tinggi Di Kabupaten Karangasem, Bali. Jurnal Sosial Ekonomi Pertanian dan Agribisnis SOCA, 12(1).

Qosim, W. A., Karuniawan, A., Marwoto, B., \& Badriah, D. S. (2020). Stabilitas parameter genetik mutan-mutan krisan generasi VM3. Laporan Hasil Penelitian Lembaga Penelitian Universitas Padjajaran.

Silaban, Y. W. (2018). Uji Daya Hasil Pendahuluan Cabairawit (Capsicum annuum L.) Generasi F5.

Singh, R. K., \& Chaudhary, B. D. (1977). Biometrical methods in quantitative genetic analysis. Biometrical methods in quantitative genetic analysis.

Vivaldy, L. A, Ratulangi, M.M \& Manengkey, G. S. J. (2017, July). Insidensi penyakit virus pada tanaman cabai (Capsicum anuum) di Desa Kakaskasen II Kecamatan Tomohon Utara Kota Tomohon. In COCOS (Vol. 1, No. 6).

Yadav, R. K., Jayanthi, P. K., Kumar, M., Saravan, P., Kumar, V., \& Reddy, K. M. (2020). Screening chilli genotypes for whitefly (Bemisia tabaci Genn.) resistance: A vector for chilli leaf curl virus. IJCS, 8(1), 971-979.

Zen, S., \& Bahar, H. (1996). Penampilan dan pendugaan parameter genetik tanaman jagung. Agric. J, 3, 1-9. 